\title{
PENINGKATAN HASIL BELAJAR PESERTA DIDIK PADA MATERI SISTEM PERSAMAAN LINEAR DUA VARIABEL MELALUI MODEL PEMBELAJARAN FLIPPED CLASSROOM
}

\author{
Aprisa Wihinda ${ }^{1}$, Theresia Laurens ${ }^{2}$, Anderson L Palinussa ${ }^{3^{*}}$ \\ 1, 2,3Prodi Pendidikan Matematika, Fakultas Keguruan dan Ilmu Pendidikan, Universitas Pattimura \\ Jalan Ir. Putuhena, Kampus Unpatti, Poka, Ambon, Indonesia \\ e-mail: ${ }^{3}$ apalinussa@yahoo.com;
}

corresponding author*

\begin{abstract}
Abstrak
Penelitian ini bertujuan untuk mengetahui peningkatan hasil belajar peserta didik pada materi sistem persamaan linear dua variabel melalui model pembelajaran flipped classroom di kelas VIII SMP Negeri 15 Ambon. Subjek penelitian ini adalah peserta didik kelas VIII6 SMP Negeri 15 Ambon yang berjumlah 25 orang, jenis penelitian ini adalah penelitian tindakan kelas. Penelitian ini dilaksanakan dalam tiga siklus dengan 5 pertemuan. Data penelitian ini dikumpulkan melalui lembar observasi dan tes. Hasil analisis menunjukkan bahwa setelah diberikan tindakan pada siklus I peserta didik yang mencapai ketuntasan sebanyak 6 orang dengan pencapaian 24\%, dan pada siklus II diperoleh jumlah peserta didik yang mencapai ketuntasan 11 orang dengan pencapaian $44 \%$, selanjutnya pada siklus III terjadi peningkatan yaitu diperoleh jumlah peserta didik yang mencapai ketuntasan 23 orang dengan pencapaian $92 \%$. Dilihat hasil tes peserta didik dari siklus II dan siklus III maka telah terjadi peningkatan yaitu sebesar $48 \%$ dengan menggunakan model pembelajaran flipped classroom pada materi sistem persamaan linear dua variabel di kelas VIII SMP Negeri 15 Ambon
\end{abstract}

Kata Kunci: hasil belajar, flipped classroom

\section{IMPROVING STUDENT LEARNING OUTCOMES ON THE MATERIAL OF TWO-VARIABLE LINEAR EQUATIONS SYSTEM THROUGH FLIPPED CLASSROOM LEARNING MODELS}

\begin{abstract}
This study aims to improve student learning outcomes in the material of two- variable linear equations system through flipped classroom learning models in VIII grade students of SMP Negeri 15 Ambon. The subjects of this study were 25 students of grade VIII6 SMP Negeri 15 Ambon, this type of research was classroom action research. This research was conducted in three cycles with 5 meetings. The research data was collected through observation and test. The results of the analysis showed that in the first cycle there were 6 students or $24 \%$ who achieved KKM, and in the second cycle there were 11 students or $44 \%$ who achieved KKM, and the third cycle there were 23 students or $92 \%$ who achieved KKM. Based on the result test of students from cycle II and cycle III there has been an increase of $48 \%$ using the flipped classroom learning models on the material of two- variable linear equations system in VIII grade students of SMP Negeri 15 Ambon
\end{abstract}

Keywords: learning outcomes, flipped classroom

\section{Pendahuluan}

Menurut Soedjadi (2007: 23), metematika memegang peran penting dalam membentuk peserta didik menjadi berkualitas, karena matematika merupakan suatu sarana yang membuat peserta didik dapat bernalar dan berfikir secara logis, analitik, kritis, kreatif, dan dapat bekerja sama. Begitu juga dengan pendapat
Ratumanan (2002), bahwa pengajaran matematika saat ini kurang memberikan perhatian mengenai aktivitas peserta didik serta pendidik terlalu mendominasi kegiatan belajar mengajar yang mengakibatkan peserta didik secara pribadi tidak kreatif, tidak kritis, harap gampang, dan tidak menkontruksikan pengetahuannya. 
Peneliti melakukan wawancara terhadap guru mata pelajaran matematika di kelas VIII SMP Negeri 15 Ambon, diperoleh informasi bahwa kriteria ketuntasan minimal (KKM) untuk setiap jenjang kelas itu berbeda-beda namun untuk kelas VIII tersebut adalah sebesar 73. Dari kriteria ketuntasan minimal 73 yang ditentukan ada beberapa peserta didik yang dikatakan belum memenuhi ketuntasan dari ketentuan kriteria ketuntasan minimal tersebut. Hal ini menunjukkan bahwa hasil belajar yang dicapai peserta didik masih dikatakan rendah, Karena kurang adanya kesiapan serta penanaman konsep dari peserta didik dalam menghadapi proses pembelajaran. Menurut salah satu pendidik bidang studi matematika dikelas VIII SMP Negeri 15 Ambon, mengatakan bahwa salah satu materi yang dianggap susah atau yang menjadi kendala dalam proses pembelajaran adalah sistem persamaan linear dua variabel.

Materi sistem persamaan linear dua variabel merupakan bagian dari aljabar yang dipelajari pada kelas VIII semester ganjil sesuai kurikulum 2013 revisi 2017 yang digunakan oleh sekolah tersebut. Berdasarkan mata pelajaran matematika SMP Negeri 15 Ambon bahwa selama 10 tahun ia mengajar, menurutnya kesulitan yang sering terjadi adalah kurangnya pemahaman konsep pada materi sistem persamaan linear dua variabel, sehingga peserta didik masih mengalami kesulitan untuk membuat model matematika dari soal cerita yang diberikan yaitu membedakan variabel yang akan digunakan. Hal tersebut sangat mempengaruhi nilai dari hasil belajar peserta didik.

Dalam proses pembelajaran yang terjadi di kelas VIII SMP Negeri 15 Ambon, umumnya pendidik telah menggunakan model pembelajaran kooperatif. Model pembelajaran kooperatif merupakan sebuah kelompok strategi pengajaran yang melibatkan peserta didik bekerja secara berkolaborasi untuk mencapai tujuan bersama, dalam penguasaan konsep dan ketrampilan yang dilakukan peserta didik. Untuk menguasai konsep yang diberikan peserta didik harus mempelajari materi yang akan diberikan terlebih dahulu sebagai modal dalam proses belajar mengajar yang akan berlangsung. Kenyataannya ada beberapa peserta didik yang belum sepenuhnya menguasai konsep pembelajaran, ini mengakibatkan sulitnya peserta didik dalam menerima pembelajaran di kelas serta kurangnya keaktif peserta didik.

Berdasarkan hal tersebut maka perlu diterapkan model pembelajaran yang dapat membuat penanaman konsep peserta didik sebelum pembelajaran berlangsung. Salah satu cara untuk membuat penanaman konsep serta meningkatkan hasil belajar peserta didik tersebut adalah menggunakan model pembelajaran flipped classroom. Model pembelajaran flipped classroom (Bergmann \& Sams, 2012:13), adalah salah satu model yang tidak seperti proses pembelajaran pada umumnya, yaitu ketika pembelajaran yang seperti biasa dilakukan di kelas kini dilakukan peserta didik di rumah, dan pekerjaan rumah yang biasanya dilakukan kini dikerjakan di sekolah. Menurut Steel (Adhitiya, dkk, 2015: 118) membagi model pembelajaran flipped classroom dalam empat langkah, yaitu:

a. Peserta didik menonton video pembelajaran di rumah

b. Datang ke kelas untuk melakukan kegiatan dan mengerjakan tugas yang berkaitan dengan video tersebut

c. Menerapkan kemampuan peserta didik dalam diskusi kelompok

d. Mengukur pemahaman peserta didik pada akhir materi pembelajaran

Model ini bukan hanya sekedar belajar dengan dibantu oleh media video melainkan, bagaimana memaksimalkan waktu di dalam kelas bersama peserta didik serta meningkatkan hasil belajar peserta diidk, inspirasi, dan membantu mereka dengan proyek-proyek yang menantang serta memberikan kontrol belajar yang lebih besar.

Berdasarkan latar belakang tersebut, maka rumusan masalah dalam penelitian ini adalah Apakah melalui model pembelajaran flipped classroom pada materi sistem persamaan linear dua variabel dapat meningkatkan hasil belajar peserta didik di kelas VIII SMP Negeri 15 Ambon?

Adapun tujuan penelitian ini adalah Untuk meningkatkan hasil belajar peserta didik pada materi sistem persamaan linear dua variabel melalui model pembelajaran flipped classroom di kelas VIII SMP Negeri 15 Ambon.

\section{Metode Penelitian}

\subsection{Tipe Penelitian}

Tipe penelitian yang digunakan dalam penelitian ini adalah penelitian kualitatif dengan model Penelitian Tindakan Kelas (PTK). PTK adalah suatu jenis penelitian reflektif yang melibatkan suatu tindakan (treatment) yang diberikan pada siswa. Selanjutnya Suharsimi (Lekitoo, dkk, 2018: 46) menggambarkan model PTK dalam bagan sebagai berikut: 


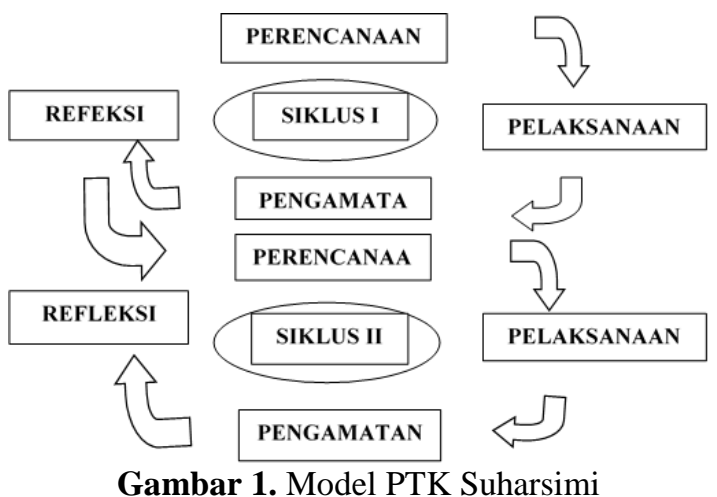

\subsection{Subjek Penelitian}

Subjek dalam penelitian ini adalah peserta didik kelas VIII SMP Negeri 15 Ambon pada tahun ajaran 2019/2020 yang berjumlah 29 orang. Sampai akhir penelitian hanya terdapat 25 orang yang mempunyai data lengkap, sehingga data inilah yang digunakan untuk dianalisis

\subsection{Prosedur Penelitian}

Penelitian tindakan kelas ini terdiri dari 3 siklus. Siklus pertama dan kedua sama-sama memiliki 2 pertemuan, sedangkan siklus ketiga hanya memiliki 1 pertemuan. Pada siklus ketiga peneliti membuat satu pertemuan dikarenakan materi yang diajarkan telah selesai serta kriterial penelitian sudah dipenuhi maka penelitian dihentikan dan langsung melakukan evaluasi sehingga tidak ada pertemuan selanjutnya

\subsection{Teknik Pengumpulan Data}

Teknik yang digunakan untuk mengumpulkan data dalam penelitian ini adalah:

a. Hasil tes peserta didik pada akhir tiap siklus

b. Lembar observasi kegiatan pendidik dan peserta didik selama proses pembelajaran berlangsung

\subsection{Teknik Analisa Data}

Teknik analisis data yang digunakan adalah analisis data kuantitatif dan kualitatif. Analisis data kuantitatif dalam penelitian ini menggunakan statistik deskriptif untuk menghitung hasil belajar peserta didik yang diperoleh sebelum dan sesudah tindakan, rumus yang digunakan adalah:

$$
\text { Hasil Belajar }=\frac{\text { Skor yang diperoleh }}{\text { Skor total }} \times 10
$$

Dari nilai yang diperoleh, kemudian diklasifiksikan tingkat ketuntasan peserta didik menurut Kriteria Ketuntasan Minimal yang telah ditetapkan SMP Negeri 15 Ambon yaitu:

Tabel 1. Kriteria Ketuntasan Minimal (KKM)

\begin{tabular}{cc}
\hline $\mathbf{( K K M )}$ & Keterangan \\
\hline$\geq 73$ & Tuntas \\
$<73$ & Belum Tuntas \\
\hline
\end{tabular}

Menghitung ketuntasan klasikal atau persentase peserta didik yang mencapai Kriteri Ketuntasan Minimal (KKM), rumus yang digunakan adalah:

$$
\text { Persentase }=\frac{\text { Siswa yang mencapai KKM }}{\text { Seluruh siswa }} \times 100
$$

Menurut Suryosubroto (2009) seorang peserta didik dikatakan tuntas belajar jika peserta didik tersebut mencapai skor minimal $65 \%$. Berdasarkan hal tersebut maka peneliti juga menggunakan skor minimal $65 \%$ dalam proses pembelajaran dari jumlah seluruh peserta didik yang mencapai $\mathrm{KKM} \geq 73$.

Data kualitatif yang diamati adalah aktifitas pendidik dan peserta didik melalui lembar observasi. Analisis data kualitatif dalam penelitian ini menggunakan analisis interaktif yang dikembangkan oleh Miles dan Huberman (Sugiyono, 2011: 337), terdiri atas tiga komponen kegiatan yang saling berkaitan satu sama lain yaitu: reduksi data, penyajian data dan penarikan kesimpulan.

Berdasarkan hal tersebut maka peneliti menetapkan kriteria penelitian tindakan kelas akan berhenti jika

a. $65 \%$ peserta didik mencapai $\mathrm{KKM} \geq 73$

b. $75 \%$ indikator pada lembar observasi kegiatan pendidik terlaksana oleh pendidik

c. $75 \%$ peserta didik melakukan 8 dari 11 indikator pada lembar observasi kegiatan peserta didik

\section{Hasil dan Pembahasan}

\subsection{Hasil}

Awal melakukan penelitian ini, peneliti melakukan diskusi dengan pendidik mata pelajaran Matematika SMP Negeri 15 Ambon, khususnya yang menangani kelas VIII6. Tujuannya untuk menjelaskan jenis penelitian yang akan digunakan yaitu tindakan kelas dalam meningkatkan hasil belajar peserta didik dengan menggunakan model pembelajaran flipped classroom. Peneliti juga menyiapakan perangkat pembelajaran seperti Rencana Pelaksanaan Pembelajaran (RPP), Video Pembelajaran, Tugas Rumah, dan Soal tes untuk akhir setiap siklus.

Adapun penjabaran hasil tes siklus I dalam Tabel 2 berikut.

Tabel 2. Hasil Tes Akhir Siklus I

\begin{tabular}{cccc} 
KKM & Frekuensi & $\begin{array}{c}\text { Persentasi } \\
(\%)\end{array}$ & $\begin{array}{c}\text { Keterangan } \\
\geq 73\end{array}$ \\
\hline
\end{tabular}




\begin{tabular}{cccc}
\hline$<73$ & 19 & 76 & $\begin{array}{l}\text { Belum } \\
\text { Tuntas }\end{array}$ \\
\hline Jumlah & 25 & 100 & \\
\hline
\end{tabular}

Berdasarkan Tabel 2 bahwa hasil tes akhir siklus I yang dilakukan peserta didik menujukkan ketuntasan yang mencapai KKM sebanyak 6 orang dengan persentasi $24 \%$. Sedangkan peserta didik yang belum tuntas dalam mencapai KKM sebanyak 19 orang dengan persentasi $76 \%$.

Pada data kualitatif yang diamati melalui lembar observasi kegiatan pendidik dan lembar observasi kegiatan pembelajaran peserta didik siklus I yaitu:

Tabel 3. Hasil Pada Lembar Observasi Kegiatan Pendidik Siklus I

\begin{tabular}{ccccc}
\hline Pertemuan & Point & Frekuensi & $\begin{array}{c}\text { Persentai } \\
(\mathbf{\%})\end{array}$ & Ket. \\
\hline I & $\geq 23$ & 25 & $83.33 \%$ & Tuntas \\
\hline & $<23$ & 5 & $16.67 \%$ & $\begin{array}{c}\text { Tidak } \\
\text { tuntas }\end{array}$ \\
\hline Jumlah & & $\mathbf{3 0}$ & $\mathbf{1 0 0 \%}$ & \\
\hline II & $\geq 20$ & 25 & $96.15 \%$ & Tuntas \\
\hline & $<20$ & 1 & $3.85 \%$ & $\begin{array}{c}\text { Tidak } \\
\text { tuntas }\end{array}$ \\
\hline Jumlah & & $\mathbf{2 6}$ & $\mathbf{1 0 0 \%}$ & \\
\hline Total & & $\mathbf{5 6}$ & $\overline{\boldsymbol{x}_{\mathbf{1}}}=\mathbf{8 9 . 2 8} \%$ \\
\hline
\end{tabular}

Tabel 4. Hasil Pada Lembar Observasi Kegiatan Pembelajaran Peserta Didik Siklus I

\begin{tabular}{ccccc}
\hline Pertemuan & Point & Frekuensi & $\begin{array}{c}\text { Persentai } \\
(\%)\end{array}$ & Ket. \\
\hline I & $\geq 8$ & 23 & $92 \%$ & Tuntas \\
\hline Jumlah & $<8$ & 2 & $8 \%$ & $\begin{array}{c}\text { Tidak } \\
\text { tuntas }\end{array}$ \\
\hline II & $\geq 8$ & 23 & $92 \%$ & Tuntas \\
\hline & $<8$ & 2 & $8 \%$ & $\begin{array}{c}\text { Tidak } \\
\text { tuntas }\end{array}$ \\
\hline Jumlah & & $\mathbf{2 5}$ & $\mathbf{1 0 0 \%}$ & \\
\hline Total & & $\mathbf{5 0}$ & $\overline{\boldsymbol{x}_{\mathbf{1}}}=\mathbf{9 2} \%$ \\
\hline
\end{tabular}

Berdasarkan Tabel 3 dan Tabel 4 menunjukkan bahwa pengamatan pada lembar observasi kegiatan pendidik yang diamati Observer pada siklus I rata-rata adalah $89.28 \%$ dan hasil pada lembar observasi kegiatan pembelajaran peserta didik siklus I rata-rata adalah 92\%

Pada siklus II diperoleh hasil tes seperti Tabel 5 berikut:

Tabel 5. Hasil Tes Akhir Siklus II

\begin{tabular}{|c|c|c|c|}
\hline KKM & Frekuensi & $\begin{array}{c}\text { Persentasi } \\
(\%)\end{array}$ & Keterangan \\
\hline$\geq 73$ & 11 & 44 & Tuntas \\
\hline$<73$ & 14 & 56 & $\begin{array}{l}\text { Belum } \\
\text { Tuntas }\end{array}$ \\
\hline Jumlah & 25 & 100 & \\
\hline
\end{tabular}

Berdasarkan Tabel 5 bahwa hasil tes akhir siklus II yang dilakukan peserta didik menujukkan ketuntasan yang mencapai KKM sebanyak 11 orang dengan persentasi $44 \%$. Sedangkan peserta didik yang belum tuntas dalam mencapai KKM sebanyak 14 orang dengan persentasi 56\%.

Pada data kualitatif yang diamati melalui lembar observasi kegiatan pendidik dan lembar observasi kegiatan pembelajaran peserta didik siklus II terdapat pada Tabel 6 dan Tabel 7

Tabel 6. Hasil Pada Lembar Observasi Kegiatan Pendidik Siklus II

\begin{tabular}{ccccc}
\hline Pertemuan & Point & Frekuensi & $\begin{array}{c}\text { Persentai } \\
(\mathbf{\%})\end{array}$ & Ket. \\
\hline I & $\geq 18$ & 23 & $95.33 \%$ & Tuntas \\
\hline Jumlah & $<18$ & 1 & $4.67 \%$ & $\begin{array}{c}\text { Tidak } \\
\text { tuntas }\end{array}$ \\
\hline II & $\geq 20$ & 24 & $\mathbf{1 0 0 \%}$ & \\
\hline & $<20$ & 1 & $96.15 \%$ & Tuntas \\
\hline Jumlah & & $\mathbf{2 6}$ & $\mathbf{1 0 0 \%}$ & \\
\hline Total & & $\mathbf{5 0}$ & $\overline{\boldsymbol{x}_{\mathbf{1}}}=\mathbf{9 6} \%$ \\
\hline
\end{tabular}

Tabel 7. Hasil Pada Lembar Observasi Kegiatan Pembelajaran Peserta Didik Siklus II

\begin{tabular}{ccccc}
\hline Pertemuan & Point & Frekuensi & $\begin{array}{c}\text { Persentai } \\
(\mathbf{\%})\end{array}$ & Ket. \\
\hline I & $\geq 8$ & 25 & $100 \%$ & Tuntas \\
\hline Jumlah & $<8$ & 0 & $0 \%$ & $\begin{array}{c}\text { Tidak } \\
\text { tuntas }\end{array}$ \\
\hline II & $\geq 8$ & 24 & $96 \%$ & Tuntas \\
\hline & $<8$ & 1 & $4 \%$ & $\begin{array}{c}\text { Tidak } \\
\text { tuntas }\end{array}$ \\
\hline Jumlah & & $\mathbf{2 5}$ & $\mathbf{1 0 0 \%}$ & \\
\hline Total & & $\mathbf{5 0}$ & $\overline{\boldsymbol{x}_{\mathbf{1}}}=\mathbf{9 8} \%$ \\
\hline
\end{tabular}

Berdasarkan Tabel 6 dan Tabel 7 menunjukkan bahwa pengamatan pada lembar observasi kegiatan pendidik yang diamati Observer pada siklus II rata-rata adalah $96 \%$ dan hasil pada lembar observasi kegiatan pembelajaran peserta didik siklus II rata-rata adalah $98 \%$.

Adapun penjabaran hasil tes siklus III dalam Tabel 8 berikut:

Tabel 8. Hasil Tes Akhir Siklus III

\begin{tabular}{cccc}
\hline KKM & Frekuensi & $\begin{array}{c}\text { Persentasi } \\
(\%)\end{array}$ & Keterangan \\
$\geq \mathbf{7 3}$ & 23 & 92 & Tuntas \\
\hline$<\mathbf{7 3}$ & 2 & 8 & $\begin{array}{l}\text { Belum } \\
\text { Tuntas }\end{array}$ \\
\hline Jumlah & 25 & 100 & \\
\hline
\end{tabular}

Berdasarkan Tabel 8 bahwa hasil tes akhir siklus III yang dilakukan peserta didik menujukkan adanya peningkatan yang diperoleh, sehingga 
sebagian besar peserta didik, telah mencapai standar ketuntasan minimal yaitu $65 \%$ peserta didik mencapai nilai $\geq 73$. Ketuntasan hasil tes peserta didik yang mencapai KKM sebanyak 23 orang dengan persentasi $92 \%$. Sedangkan peserta didik yang belum tuntas dalam mencapai KKM sebanyak 2 orang dengan persentasi $8 \%$.

Sedangkan data kualitatif yang diamati melalui lembar observasi kegiatan pendidik dan lembar observasi kegiatan pembelajaran peserta didik siklus III terdapat pada Tabel 9 dan Tabel 10 dibawah ini.

Tabel 9. Hasil Pada Lembar Observasi Kegiatan Pendidik Siklus III

\begin{tabular}{ccccc}
\hline Pertemuan & Point & Frekuensi & $\begin{array}{c}\text { Persentai } \\
(\boldsymbol{\%})\end{array}$ & Ket. \\
\hline I & $\geq 22$ & 22 & $100 \%$ & Tuntas \\
\hline & $<22$ & 0 & $0 \%$ & $\begin{array}{c}\text { Tidak } \\
\text { tuntas }\end{array}$ \\
\hline Jumlah & & $\mathbf{2 4}$ & $\mathbf{1 0 0 \%}$ & \\
\hline Total & & $\mathbf{5 0}$ & $\overline{\boldsymbol{x}_{\mathbf{1}}}=\mathbf{1 0 0} \%$ \\
\hline
\end{tabular}

Tabel 10. Hasil Pada Lembar Observasi Kegiatan Pembelajaran Peserta Didik Siklus III

\begin{tabular}{ccccc}
\hline Pertemuan & Point & Frekuensi & $\begin{array}{c}\text { Persentai } \\
(\boldsymbol{\%})\end{array}$ & Ket. \\
\hline I & $\geq 8$ & 24 & $96 \%$ & Tuntas \\
\hline & $<8$ & 1 & $4 \%$ & $\begin{array}{r}\text { Tidak } \\
\text { tuntas }\end{array}$ \\
\hline Jumlah & & $\mathbf{2 5}$ & $\mathbf{1 0 0 \%}$ & \\
\hline Total & & $\mathbf{5 0}$ & $\overline{\boldsymbol{x}_{\mathbf{1}}}=\mathbf{9 6 \%}$ \\
\hline
\end{tabular}

Berdasarkan Tabel 9 dan Tabel 10 menunjukkan bahwa pengamatan lembar observasi kegiatan pendidik yang diamati Observer pada siklus III rata-rata adalah $100 \%$ dan lembar observasi kegiatan pembelajaran peserta didik siklus III rata-rata adalah $96 \%$.

Berdasarkan hasil tes, hasil pada lembar observasi kegiatan pendidik dan hasil pada lembar observasi kegiatan pembelajaran peserta didik maka pendidik AMS yang mengajar, Pendidik JH, peneliti dan 2 teman mahasiswi HN dan RA selaku observer menilai bahwa pelaksanaan tindakan perbaikan telah berhasil dilaksanakan. Maka kami sepakat untuk tidak melakukan penelitian ke siklus berikutnya. Sedangkan bagi peserta didik yang belum tuntas dalam mencapai KKM pada siklus III akan diberikan tugas dengan soal yang sejenis untuk menambah pemahaman mereka terkait materi yang telah diajarakan.

\subsection{Pembahasan}

Adapun peningkatan hasil belajar peserta didik yang terjadi dari siklus I hingga ke siklus III disajikan pada diagram berikut:

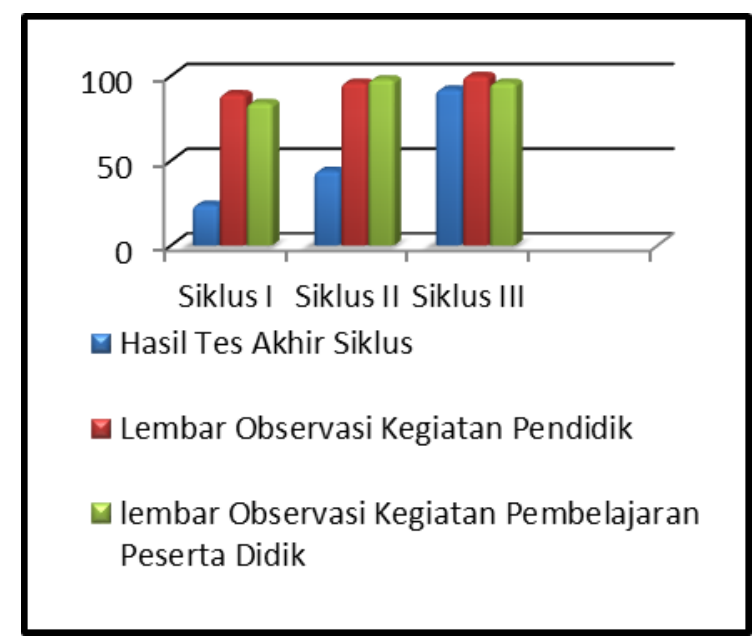

Gambar 2. Diagram Persentasi Ketuntasan

Pada siklus I, dalam tahap perencanaan dibuat rencana untuk tindakan yang akan dilakukan. Flipped classroom menjadi model pembelajaran untuk dilaksanakan kegiatan pembelajaran. Menurut data observasi, masih terdapat banyak kekurangan dari pendidik maupun peserta didik.

Kekurangan yang berasal dari pendidik yaitu pendidik belum mampu menciptakan media pembelajaran yang menarik sehingga ada sebagian peserta didik yang malas untuk menonton video yang telah diberikan. serta kurangnya kreatifitas dalam mengolah kelas, sehingga mengakibatkan hanya sebagian peserta didik yang aktif dan sebagian lainya hanya bermain serta bercerita dengan teman sebangkunya, tanpa mempedulikan apa yang telah diperintahkan pendidik, sehingga mengakibatkan Mereka tidak mampu mengajukan pendapat secara optimal selama berlangsungnya diskusi.

Selanjutnya, peserta didik diberikan tindakan. Pada siklus I menunjukkan ketuntasan yang mencapai KKM sebanyak 6 orang dengan presentasi $24 \%$. Sedangkan peserta didik yang belum tuntas dalam mencapai KKM sebanyak 19 orang dengan persentasi $76 \%$. Tes ini dilakukan secara individu dan dilaksanakan pada akhir pertemuan kedua siklus I. Berdasarkan hasil tes akhir siklus yang belum mencapai kriteria ketuntasan minimal yang telah ditetapkan, maka pendidik, peneliti, dan para observer berniat untuk melanjutkan penelitian ini pada siklus berikutnya.

Pelaksanaan tindakan pada siklus II ini, dilaksanakan agar dapat memperbaiki kekurangankekurangan yang ada pada siklus I. Namun hasil tes akhir siklus II yang dilakukan belum tercapainya ketuntasan $\mathrm{KKM} \geq 73$. Berdasarkan hasil tes akhir siklus terdapat sebanyak 11 orang dengan presentasi $44 \%$, sedangkan peserta didik yang belum tuntas dalam mencapai KKM sebanyak 14 
orang dengan presentasi $56 \%$. Jika dilihat dari peningkatan hasil belajar yang terjadi, maka dapat disimpulkan telah terjadi perbaikan pada siklus yang kedua, akan tetapi semua belum mencapai kriteria ketuntasan minimal yang telah ditetapkan. Hal ini disebabkan karena banyaknya kekurangan yang juga terjadi pada siklus II, sama seperti pelaksanaan tindakan pada siklus I. Namun pada tahap pelaksanaan siklus II ini, kekurangan yang terjadi dapat diminimalisir secara bertahap. Adapun interaksi yang terjadi antara pendidik dengan peserta didik dan juga sesama peserta didik belum berjalan seperti yang diinginkan. Sehingga peserta didik dinilai belum berperan aktif dalam menanggapi persoalan yang terjadi selama berlangsungnya diskusi. Untuk memperbaiki semua itu, maka dilakukan pelaksanaan tindakan siklus ke III.

Pada pelaksanaan siklus III kembali digunakan model pembelajaran flipped classroom untuk memperbaiki kekurangan-kekurangan yang ada pada siklus I dan II. Adapun kekurangan yang terjadi pada siklus III ini sudah dapat diperbaiki secara baik. Selama proses diskusi berlangsung, sebagian besar peserta didik dari masing-masing kelompok telah menunjukkan rasa antusiasnya dalam mengikuti proses pembelajaran. Pendidik juga sudah mampu mengolah dan mengontrol suasana kelas sehingga dapat terciptanya suasana yang aman dan tertib.

Hasil tes siklus III menujukkan adanya peningkatan yang diperoleh, sehingga rata-rata tes hasil belajar peserta didik adalah $92 \%$ yang telah mencapai standar ketuntasan minimal yaitu $65 \%$ mencapai nilai $\geq 73$. Ketuntasan hasil tes peserta didik yang mencapai KKM sebanyak 23 orang dengan persentasi $92 \%$, sedangkan peserta didik yang belum tuntas dalam mencapai KKM sebanyak 2 orang dengan persentasi $8 \%$, akan diberikan tugas dengan soal tes yang sejenis.

Berdasarkan hasil refleksi pada siklus III, Maka dapat dikatakan pelaksanaan tindakan siklus III dapat diperbaiki dan berjalan dengan baik. Hal ini menunjukkan bahwa hipotesis tindakan telah tercapai yaitu ada peningkatan hasil belajar peserta didik di kelas VIII SMP Negeri 15 Ambon pada materi sistem persamaan linear dua variabel dengan menggunakan model pembelajaran flipped classroom.

Berikut adalah paparan dialog singkat aktivitas pendidik (P) dan aktivitas peserta didik (PD) selama proses pembelajaran dikelas.

$\mathrm{P} \quad$ : Apakah anak-anak telah menonton serta mengerjakan tugas yang ibu berikan?
P : dari tugas yang ibu berikan, adakah yang belum dipahami?

PD : ada ibu, saya mau menanyakan apa yang dimaksud dengan varibel bergantung?

$\mathrm{P} \quad$ : Variabel bergantung yaitu variabel yang saling terikat dengan variabel lainnya. Contoh rumus luas segiempat $(L=S \times S)$ Variabel yang digunakan apa saja anak-anak?

PD : L dan $S$

$\mathrm{P} \quad$ : Sekarang yang merupakan variabel tergantung/ terikat adalah $L$ karena semakin tinggi nilai variabel $S$ maka semakin besar juga nilai dari variabel $L$. Dari sini ada pertanyaan lainnya? Klau tidak ada, sekarang anak-anak ibu bentuk menjadi beberapa kelompok untuk membahas tugas yang telah dikerjakan dirumah dan dapat di pertanggung jawabkan di depan kelas.

Dalam penelitian ini, terdapat salah satu kelemahan yaitu pada akhir siklus I dan II peneliti tidak memberikan tugas kepada peserta didik yang belum tuntas, sehingga dalam penelitian ini terdapat tiga siklus untuk mencapai tujuan yang diharapkan.

\section{Kesimpulan}

Melalui model pembelajaran flipped classroom pada materi sistem persamaan linear dua variabel dapat meningkatkan hasil belajar peserta didik di kelas VIII SMP Negeri 15 Ambon. Hal ini dilihat dari hasil tes yang diadakan tiap akhir siklus. Pada tes siklus pertama peserta didik yang mendapatkan $\mathrm{KKM} \geq 73$ sebanyak 6 orang sehingga presentasenya adalah $24 \%$. Kemudian, pada siklus kedua peserta didik yang pencapaian $\mathrm{KKM} \geq 73$ sebanyak 11 orang dengan presentase $44 \%$. Setelah itu, pada siklus ketiga peserta didik yang mendapatkan KKM $\geq 73$ sebanyak 23 orang dengan presentase $92 \%$. Dilihat hasil tes peserta didik dari siklus II dan siklus III maka telah terjadi peningkatan yaitu sebesar $48 \%$.

\section{Daftar Pustaka}

Adhitiya, E.N., Prabowo, A., Arifudin, R. (2015). Studi Komparasi Model Pembelajaran Traditional Flipped dengan Peer Instruction Flipped Terhadap Kemampuan Pemecahan Masalah. Unnes Journal of Mathematics Education. Tersedia: http://journal.unnes.ac.id/sju/index.php/ujme diakses pada 14-05-2019. 
Bergmann, J. \& Sams, A. (2012). Flip Your Classroom: Reach every student in every class every day (First Edition). United States of America: iste. Tersedia: https://doi.org/10.1111/teth.12165

Lekitoo, J., Moma, L., \& Ngilawajan, D. (2018). Peningkatan Hasil Belajar Siswa Kelas XI SMA Negeri 4 Ambon Pada Materi Irisan Kerucut Dengan Menggunakan Model Pembelajaran Kooperatif Melalui Media Pembelajaran CAI (Computer Assisted Instruction) Berbantuan Software Geogebra. Jurnal Pendidikan Matematika (Jupitek), 1(1), 41-46.
Ratumanan, T. G. (2002). Belajar dan Pembelajaran. Surabaya: Unesa Press.

Soedjadi, R. 2007. Masalah Kontekstual Sebagai Batu Sendi Matematika Sekolah. Surabaya: Pusat Sains dan Matematika Sekolah (PSMS).

Sugiyono. (2011). Metode Penelitian Kuantitatif, Kualitatif dan R\&D. Bandung: Afabeta.

Suryosubroto. 2009. Proses belajar mengajar di Sekolah. Jakarta: Rhineka Cipta. 